American J. of Engineering and Applied Sciences 2 (1):189-193, 2009

ISSN 1941-7020

(C) 2009 Science Publications

\title{
The Effect of Electrical Properties by Texturing Surface on GaAs Solar Cell Efficiency
}

\author{
${ }^{1}$ H. Abdullah, ${ }^{1}$ A. Lennie, ${ }^{2}$ M.J. Saifuddin and ${ }^{3}$ I. Ahmad \\ ${ }^{1}$ Department of Electrical, Electronics and Systems Engineering, \\ Faculty of Engineering and Built Environment, \\ University Kebangsaan Malaysia, 43600 Bangi, Selangor Malaysia \\ ${ }^{2}$ University of Malikussaleh, Lancang Garam Lhokseumawe, Nanggro Aceh Darussalam, Indonesia \\ ${ }^{3}$ Department of Electronic and Communication Engineering, College of Engineering, \\ University Tenaga Malaysia, 43009 Kajang, Selangor, Malaysia
}

\begin{abstract}
Problem statement: This project discusses on the method to resolve the optical losses problem that have been hindering the totality efficiency of the photovoltaic. Solar cell simulation could be useful for time saving and cost consumption. The Silvaco software is not widely used in designing the 2D solar cell devices because there is lots of 1D, 2D and 3D-simulation beside Silvaco software such as MicroTec, SCAPS-1D. Approach: The different models surface texturing on GaAs solar cell had been simulated by using the Virtual Wafer Fab (VWF), SILVACO software in this project. Results: It was expected that modification of surface texturing might distinctly improved the spectral sensitivity of the photovoltaic by reducing the light reflection and improving the light trapping. There are four models surface texture of photovoltaic devices. It is the simple structure, V-trench structure, fours-sided structure and semi-sphere structure. Hence, the incoming light will hit the GaAs surface several times. Light, which is not absorbed in its first passage through the cell, has the additional opportunities to be absorbed into the cell. It had been shown that modified surface of GaAs solar cell had improved the efficiency up to more than $2 \%$ and its quality application performance about $10 \%$. Conclusion: From the simulation result, the V-trench structure is the best surface texture for GaAs solar cell compared to the others, which has $\mathrm{J}_{\mathrm{sc}}$ is $3.575 \mathrm{~mA} \mathrm{~cm}{ }^{-2}, \mathrm{~V}_{\mathrm{oc}}$ is $0.807 \mathrm{~V}$ and efficiency is $23.07 \%$ in $90^{\circ}$ incident light.
\end{abstract}

Key words: Surface Textured, GaAs Solar Cell, Short Circuit Current Density, Open Circuit Voltage, Silvaco

\section{INTRODUCTION}

Current solar cell simulation tools typically use discrete components to model one aspect of solar cell operation. These can be very accurate predictors of specific characteristics. This simulation can be done much faster than physical experimentation and can provide solar cell information that is difficult or impossible to measure, but lack the breadth of a complete model and are thereby limited in their usefulness as design tools. A good solar cell simulation involves all the best models for each part a manufacturing processes. Ion implantation is one of the first steps in $\mathrm{p}-\mathrm{n}$ junction processing that could effect on the final results ${ }^{[1,2,4]}$. In the single $p$-n junction of GaAs solar cell, Simulation is one of the steps used to investigation defective devices. The simulation involves ATHENA and ATLAS as sub component from Silvaco Packages software ${ }^{[5]}$. It is an appropriate set of layer junction patterns applied to the solar cell, to open circuit voltage and short circuit current on the final result outputs. It was shown surface texturing can be considered as a good candidate to solve the problem efficiency of solar cell. When the surface was textured, the lights are traveled more inside the cell and absorption of it was increased as the length of traveling increased. This novel model extracts the electrical characteristics of a solar cell based on virtual fabrication of its physical structure, allowing for direct manipulation of materials and doping. As a pre-design of solar cell, there will have an effect of texturing pn junction GaAs solar cell.

Corresponding Author: H. Abdullah, Department of Electrical, Electronics and Systems Engineering,

Faculty of Engineering and Built Environment, University Kebangsaan Malaysia, 43600 Bangi, Selangor Malaysia 
The short current or short-circuit current of a solar cell is the result of the contribution of the current generated in its different regions. The photon flux in emitter, depletion zone and base generates carriers, which are accelerated by the junction electric field and collected in the front and back metal contacts. A percentage of the generated carriers recombines in the bulk and interfaces. The minority carries lifetime or diffusion length in the base and emitter are the global parameters, which governs the recombination losses. The spectral response, SR is the parameter that determines the ratio of collected carriers with respect to the incoming photon flux at a given wavelength ${ }^{[3]}$. The internal spectral response or quantum efficiency is given by:

$$
\mathrm{SR}_{\text {int }}(\lambda)=\frac{\mathrm{J}_{\mathrm{ph}}(\lambda)}{\mathrm{q} \varphi(\lambda)(1-\mathrm{R}(\lambda))}
$$

where, $\mathrm{J}_{\mathrm{ph}}(\lambda)$ is the current density at a given wavelength, $\mathrm{q}$ is the electron charge, $\varnothing(\lambda)$ is the monochromatic photo-flux and $R(\lambda)$ is the reflectivity. The short-circuit current can be calculated by the integration of Eq. 1:

$$
\mathrm{J}_{\mathrm{sc}}=\mathrm{q} \int_{0}^{\lambda_{\mathrm{m}}} \varphi(\lambda)[1-\mathrm{R}(\lambda)] \mathrm{SR}_{\text {int }}(\lambda) \mathrm{d} \lambda
$$

where, $\lambda_{\mathrm{m}}$ is the wavelength corresponding to the photon energy equal to the band gap. The DICE analysis $^{[9]}$ permits the calculation of short-circuit current by the following equation:

$$
\mathrm{J}_{\mathrm{sc}}=\mathrm{q} \int_{0}^{\mathrm{w}} \varphi(\mathrm{x}) \mathrm{D}(\mathrm{x}) \mathrm{dx}
$$

where, $\mathrm{D}(\mathrm{x})$ is the DICE parameter and $\varnothing(\mathrm{x})$ is given by:

$$
\varphi(x)=\int_{0}^{\lambda_{\mathrm{m}}} \mathrm{x}(\lambda) \varphi(\lambda)[1-\mathrm{R}(\lambda)] \exp (-\mathrm{x} \alpha(\lambda)) \mathrm{d} \lambda
$$

where, $\alpha(\lambda)$ is the absorption coefficient ${ }^{[7]}$.

The cell generates the maximum power $\mathrm{P}_{\max }$ at a voltage $V_{m}$ and current $I_{m}$ and it is convenient to define the fill factor FF by:

$$
\mathrm{FF}=\frac{\mathrm{I}_{\mathrm{m}} \cdot \mathrm{V}_{\mathrm{m}}}{\mathrm{I}_{\mathrm{sc}} \cdot \mathrm{V}_{\mathrm{oc}}}=\frac{\mathrm{P}_{\mathrm{max}}}{\mathrm{I}_{\mathrm{sc}} \cdot \mathrm{V}_{\mathrm{oc}}}
$$

At Air Mass 1.5 (AM 1.5), the efficiency of solar cell, $\eta_{\mathrm{s}}$ is given by, where $\mathrm{P}_{\mathrm{m}}=1000 \mathrm{~W} \mathrm{~m}^{-2}$ in $\mathrm{AM}$ 1.5:
$\eta_{\mathrm{s}}=\frac{\mathrm{I}_{\mathrm{sc}} \cdot \mathrm{V}_{\mathrm{oc}} \cdot \mathrm{FF}}{\mathrm{P}_{\mathrm{m}}}$

\section{MATERIALS AND METHODS}

ATLAS predicts the electrical characteristics of physical structures by simulating the transport of carriers through a 2D grid $^{[5-7]}$. The accuracy of this physically based simulation tool depends greatly on the accuracy of the material parameters used in constructing the solar cell model. Important parameters needed for solar cell modeling in ATLAS include band gap energy, electron and hole state densities, electron and hole motilities, permittivity, electron affinity, radiative recombination rate and optical parameters. One of the most critical parameters for advanced solar cell modeling is the correct definition of the refractive index, $\mathrm{n}$ and the extinction coefficient, $\mathrm{k}$, for a material. Many of the advanced ternary and quaternary materials have limited published optical parameters. Good approximations of the $\mathrm{n}$ and $\mathrm{k}$ values may be obtained through interpolation between simpler compounds. Once a solar cell is simulated in ATLAS, it may be illuminated with a constant wavelength of light or a complex spectrum such as Air Mass Zero (AM0) spectrum, which represents the solar spectrum for earth orbiting spacecrafts. A wide variety of outputs are available to the solar cell designer. These include I-V characteristics, spectral response, potential build-up, electrostatic field and photo generation rate ${ }^{[5,7-9]}$. The solar cell that has been chosen for test is made in usual method in VLSI. A <100> orientation GaAs wafer of $10 \mu \mathrm{m}$ thickness and $1 \times 10^{14} \mathrm{~cm}^{-3}$ boron concentration was chosen as substrate. The pn junction was developed by implant process of phosphorus doping with $1 \times 10^{17} \mathrm{~cm}^{-3}$ and energy $5 \mathrm{eV}$. The diffuse time $300 \mathrm{~min}$ and temperature $900^{\circ} \mathrm{C}$ are constant. By changing four variables of surface texture solar cells with the single pn junction could be structured by using etching process (Fig. 1). By plotting the J-V characteristics graph, a simple surface solar cell could be compared to the other three textured surfaces for 30,60 and $90^{\circ}$ of incident lights.

\section{RESULTS AND DISCUSSION}

In this project, four models of GaAs solar cell with different texturing surface have been investigated. Figure 1 shown the direction of $90^{\circ}$ incident lights when applying into four models of solar cell surfaces. For simple surface, there is no reflectance light into substrate when applying $90^{\circ}$ incident lights. 


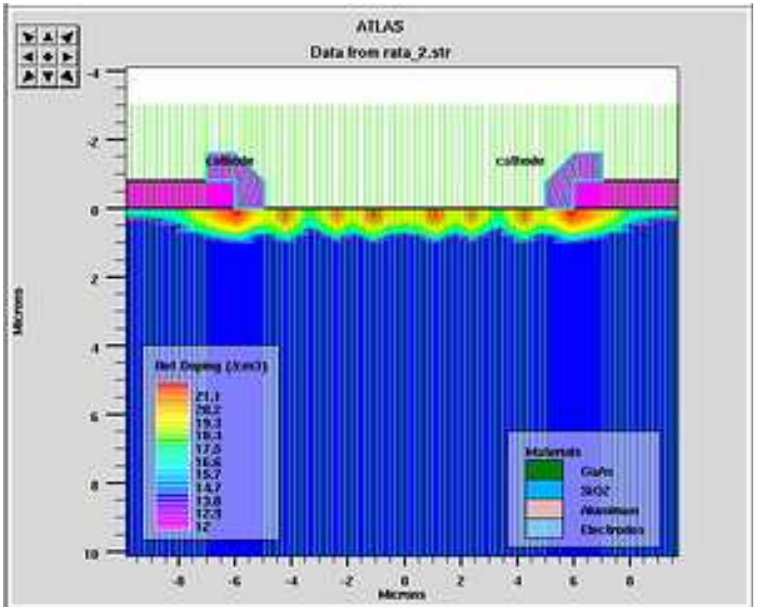

(a)

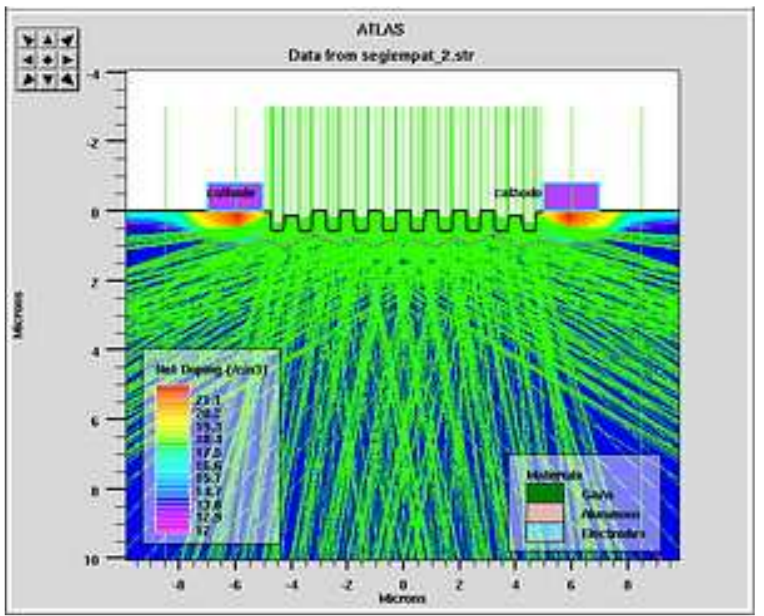

(c)

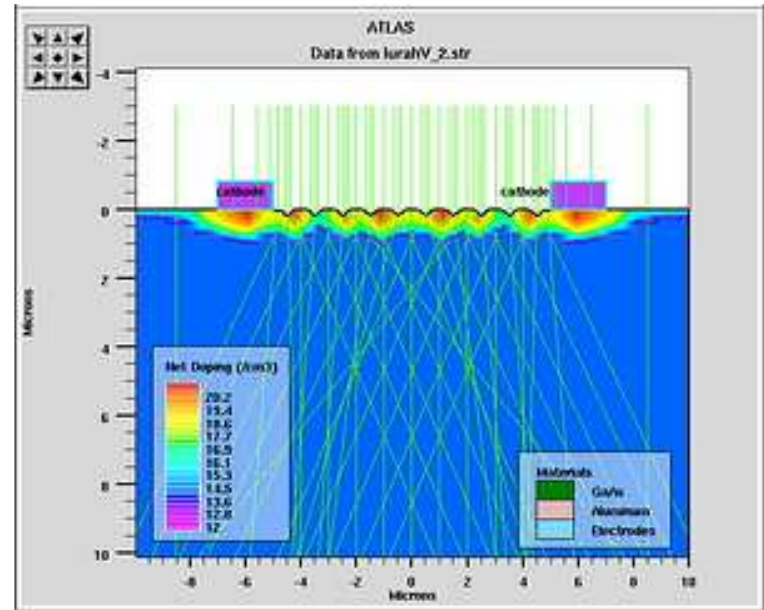

(b)

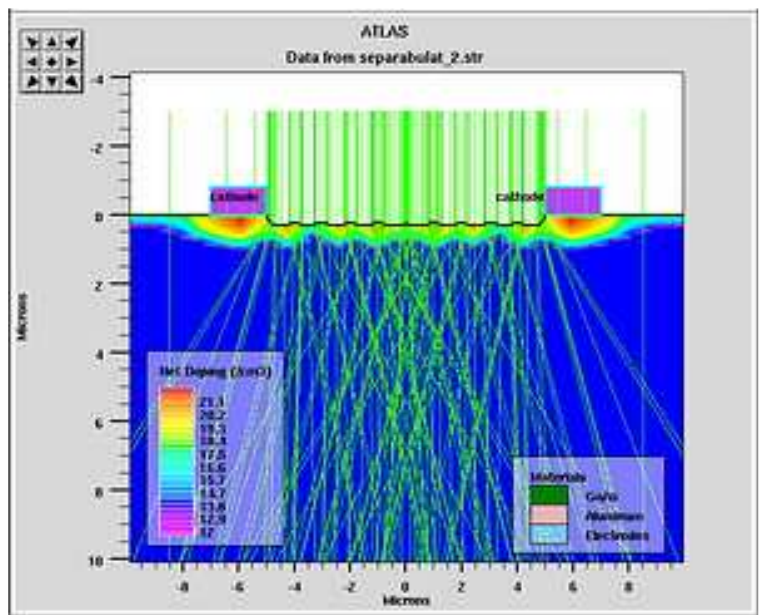

(d)

Fig. 1: The solar cell simulation of (a): Simple surface solar cell; (b): V-trench structure; (c): Four-sided structure and (d): Semi-sphere structure in $90^{\circ}$ incident lights

Meanwhile the V-trench surface absorbed less incident light compared to semi-sphere surface. From Fig. 1, it shows the incident light on four-sided textured surface is absorbed more reflectance light in substrate compared to other surfaces. This situation cause of the shape of surface is rectangular channel.

Figure 2 shown the V-trench solar cell structure of 30, 60 and $90^{\circ}$ of incident lights. In Fig. 2 shows the light of $90^{\circ}$ is more reflected than $30^{\circ}$ and $60^{\circ}$ incident light when the lights entering into GaAs substrate. When the angle of incident light is decreased, the absorbed light also decreased when entering into substrate. The main objective in this project is to enhance the short circuit current density, $\mathrm{J}_{\mathrm{sc}}$ by texturing the surface of solar cell virtual devices. The values of $\mathrm{J}-\mathrm{V}$ characteristics from a simple surface (rata) solar cell has been compared with the three different surface textures; V-trench surface (lurahV), four-sided surface (empatsegi) and semi-sphere surface (separabulat) of solar cells are shown in Table 1.

The details simulation result of short circuit current density, $\mathrm{J}_{\mathrm{sc}}$ and open circuit voltage, $\mathrm{V}_{\mathrm{oc}}$ on GaAs solar cell textured surfaces for variables angles of incident light are recorded in Table 1 below. From this table could see the $\mathrm{J}_{\mathrm{sc}}$ from 30 and $60^{\circ}$ is lower than $90^{\circ}$ lights, but the $\mathrm{V}_{\mathrm{oc}}$ of all light angles are constantly around $0.75-0.81 \mathrm{~V}$. In overall shows the highest $\mathrm{J}_{\mathrm{sc}}$ is $3.584 \mathrm{~mA} \mathrm{~cm}{ }^{-2}$ from semi-sphere GaAs solar cell, meanwhile the highest $\mathrm{V}_{\mathrm{oc}}$ is $0.807 \mathrm{~V}$ from $\mathrm{V}$-trench GaAs solar cell. Those values were both in $90^{\circ}$ light incidents. This table we can see after modification of surface texture has been done, the efficiency of solar cell could be increased when the $\mathrm{J}_{\mathrm{sc}}$ also increased. 
Am. J. Engg. \& Applied Sci., 2 (1):189-193, 2009
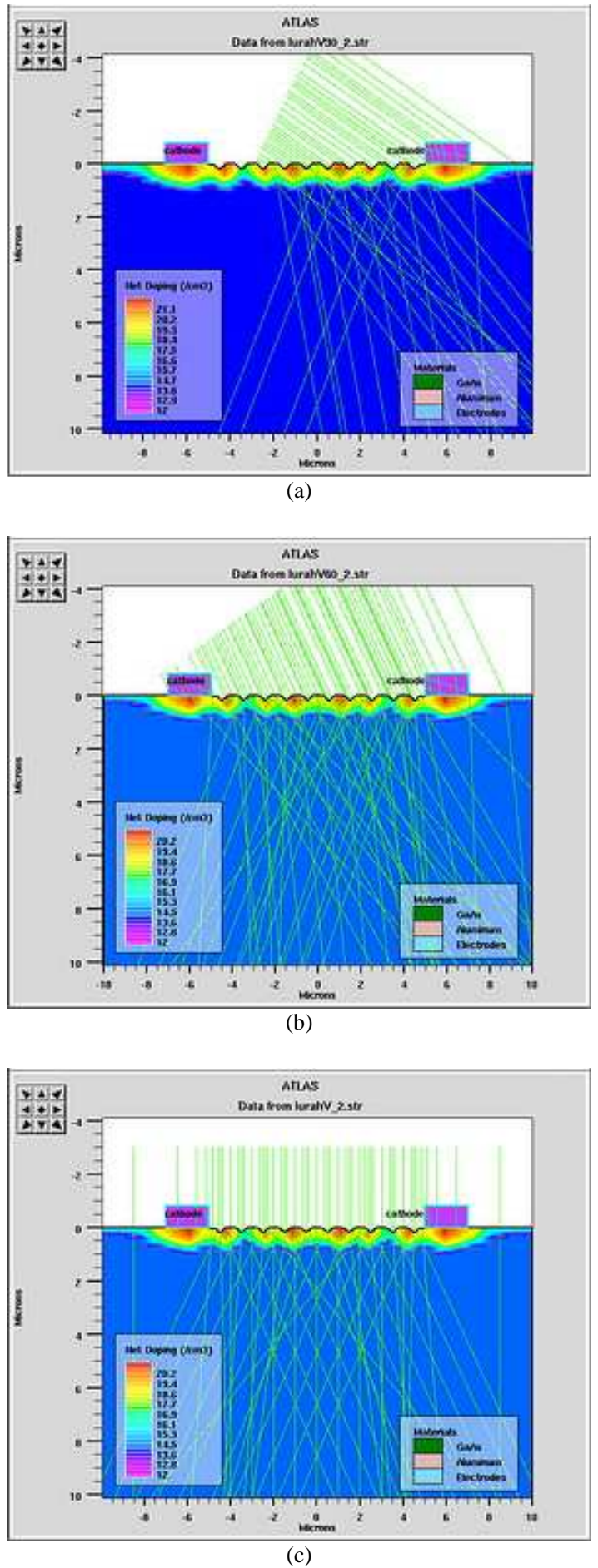

Fig. 2: The V-trench solar cell structure in 30, 60 and $90^{\circ}$ incident light. (a): V-trench solar cell in $30^{\circ}$ incident light; (b): V-trench solar cell in $60^{\circ}$ incident light and (c) V-trench solar cell in $90^{\circ}$ incident light
Table 1: The electrical characteristics of $30^{\circ}, 60^{\circ}$ and $90^{\circ}$ incident lights on GaAs solar cell

\begin{tabular}{|c|c|c|c|c|}
\hline \multirow{2}{*}{$\begin{array}{l}\text { Angle of } \\
\text { light } \\
\text { (degree) }\end{array}$} & \multicolumn{4}{|c|}{ Short circuit current density, $\mathrm{J}_{\mathrm{sc}}\left(\mathrm{mA} \mathrm{cm}^{-2}\right)$} \\
\hline & Simple & V-trench & Four-sided & Semi-sphere \\
\hline 30 & 0.615 & 0.637 & 0.640 & 0.636 \\
\hline 60 & 0.496 & 0.510 & 0.515 & 0.508 \\
\hline 90 & 3.280 & 3.575 & 3.570 & 3.584 \\
\hline \multicolumn{5}{|c|}{ Open circuit voltage, $\mathbf{V}_{\text {oc }}(\mathrm{V})$} \\
\hline 30 & 0.758 & 0.766 & 0.759 & 0.759 \\
\hline 60 & 0.753 & 0.806 & 0.757 & 0.754 \\
\hline 90 & 0.798 & 0.807 & 0.800 & 0.800 \\
\hline
\end{tabular}

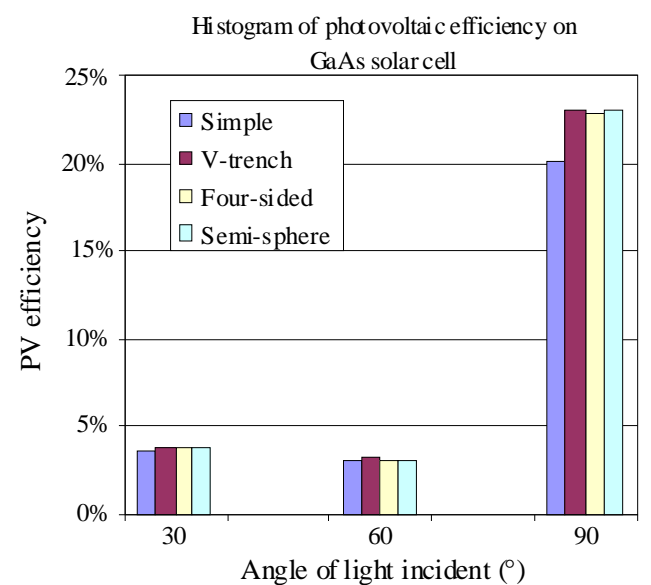

Fig. 3: The histogram of photovoltaic efficiency in 30, 60 and $90^{\circ}$ incident lights on GaAs solar cell

Figure 3 above described the histogram of efficiency in 30,60 and $90^{\circ}$ incident light when hits the solar cell surface. It is shown in overall the $30^{\circ}$ light incidents has solar cell efficiency around 3.8$3.9 \%$, meanwhile the $60^{\circ}$ incident light has efficiency around $3.0-3.3 \%$. Instead of that, the efficiency of $90^{\circ}$ incident lights on V-trench structure is higher than other surface, which has $23.07 \%$ efficiency and the lowest efficiency is $20.95 \%$ from simple structure solar cell. It is found that the modified surface of photovoltaic devices has improved the efficiency up to more than $2.12 \%$ and its quality application performance about $10 \%$. In this case, the value of Fill Factor (FF) is around 0.80. In this study can be concluded that the best surface structure for photovoltaic GaAs is $\mathrm{V}$-trench structure that compared to the others, which has $\mathrm{J}_{\mathrm{sc}}, \mathrm{V}_{\mathrm{oc}}$ and $\eta$ is $3.575 \mathrm{~mA} \mathrm{~cm}{ }^{-2}$, $0.807 \mathrm{~V}$ and $23.07 \%$, respectively, in $90^{\circ}$ incident light.

\section{CONCLUSION}

In this project can be concluded that the simulation has more advantages than physical experimentation. It 
is accurately and faster using the Silvaco packages software. Investigation will be tight efficiency to find model structure and developing of single junction solar cell. Even though the surface texturing in four models are different and net doping profile introduce different size and shape, but simulation in $\mathrm{J}-\mathrm{V}$ characteristics are shows a little bit of different values for all four models. This case could compute different efficiency of variable surface structure and angle of light incident. These results show that the V-trench is the best structure that has optimum efficiency and short circuit current density. The V-trench GaAs solar cell has $\mathrm{J}_{\mathrm{sc}}$ is 3.575 $\mathrm{mA} / \mathrm{cm}^{2}, \mathrm{~V}_{\mathrm{oc}}$ is $0.807 \mathrm{~V}$ and efficiency is $23.07 \%$ in $90^{\circ}$ incident lights. The GaAs solar cell has improved the efficiency up to more than $2 \%$ and its quality application performance about $10 \%$. This case could suggest in first step it would better using the V-trench texturing to enhance solar cell efficiency and short circuit current density.

\section{ACKNOWLEDGEMENT}

The researchers would like to thank the Ministry of Higher Education for sponsoring this work under project (UKM-RS-06-FRGS0001-2007). Also thanks to Laboratory of Advanced Semiconductor Packaging (ASPAC), Faculty of Engineering and Built Environment, University Kebangsaan Malaysia for providing the facilities.

\section{REFERENCES}

1. Ashworth, D.G., R. Oven and B. Mundin, 1990. Representation of ion implantation profiles by Pearson frequency distribution curves. J. Phys. D: Applied Phys., 23: 870-876. DOI: 10.1088/00223727/23/7/018
2. Fisher, D., 1994. Ph.D Thesis. De Neuchatel University, Switzerland.

3. Green, M.A., 1987. High Efficiency Silicon Solar Cells. Trans Tech Publications.

4. Lindhard, J., M. Scharff and H.E. Schiott. 1963. Range concepts and heavy ion ranges. Mat. Fys. Medd. Dan. Vid. Selsk., 33: 1-42.

5. Michael, S. and A. Bates, 2005. The design and optimization of advanced multijunction solar cell using the silvaco ATLAS software package. Solar Energ. Mater. Solar Cells, 87: 785-794. http://cat.inist.fr/?aModele $=$ afficheN\&cpsidt=16787648

6. Micheal, S., 2005. Silvaco Atlas as a solar cell modeling tool. Proceeding of the 31st IEEE Conference on Photovoltaic Specialists, Jan. 3-7, IEEE Xplore Press, USA., pp: 719-721. http://ieeexplore.ieee.org/xpl/freeabs_all.jsp?arnum ber $=1488232$

7. Silvaco ATLAS user's manual. 2003. Software version 5.6.O.R. Silvaco International. 1 and 2. Sunnyvale, CA.

8. Sze, S.M., 1985. Semiconductors Devices, Physics and Technology. Wiley, New York, ISBN: 9780471837046, pp: 523.

9. Takahama, T., M. Isomura, S. Tsuda, H. Tarui, Y. Hishikawa, N. Nakamura, Y. Nakashima, T. Matsuoka, H. Nishiwaki, M. Ohnishi, S. Nakano and Y. Kuwano, 1986. A new analytical method of amorphous silicon solar cells. Jap. J. Applied Phys., 25: 1538-1541. DOI: 10.1143/JJAP.25.1538 